\title{
QUALITY CONTROL ANALYSIS USING SIX SIGMA (DMAIC) METHOD TO REDUCE POST PIN ISOLATOR RIJECT IN PT XYZ (FIRING SECTION)
}

\author{
Doddy Agustiandi \\ Mercu Buana University \\ Bekasi, Indonesia
}

\begin{abstract}
This study aims to find the type of defect, along with find the main causes and providing suggestions for improvements in reducing the number of failed products in production processes of firing sections. This study uses a Six Sigma methodology approach with tools such as Fishbone diagrams, Pareto diagrams, Brainstroming and Histograms. This research is a quantitative descriptive exploratory method. The results of this study indicate the types of product failures, namely Skirt Lip Crack, Inner Skirt Crack and Broken Body. Then there are several causes of product failure is : the auger in the pugmill machine is worn, the dimensions of the Honggote (HG) shape in the forming and seizure sections are not matching, vaccum finishing is not stable, and there is no measurement of the twist of the Yobigote (YG) twist. Then, corrective actions were taken in the form of repairing the extruder and finishing machines, training the operators, making new SOPs, making checksheets and checklists for control. The conclusion of this research is that quality control using the six sigma method can reduce the rejection level and increase the six sigma level. The suggestion is the need for further research to be able to increase the six sigma level.
\end{abstract}

Keywords: Six Sigma, Quality Improvement, Fishbone Diagram, and Ceramic Insulator

\section{INTRODUCTION}

The company is one of the industries in the manufacturing sector engaged in medium voltage ceramic insulators, namely the production of $12.5 \mathrm{kN}$ pin post insulators and $70 \mathrm{kN}$ suspensions. In April 2020, the company targets a rijek level in the firing is $2.5 \%$ while the failure rate for pin post in the finishing sections is $10.12 \%$. Thus it is necessary to control the quality of production so that production defects can be reduced and product quality is maintained.

Researchers chose quality control using Six Sigma because "Six Sigma is a new management tool used to improve Total Quality Management, very focused on quality control by exploring the company's overall production system which aims to eliminate production defects" (SHIFT Indonesia, 2017). Six Sigma is considered better than other methods such as Total Quality Management (TQM), TQM is a method for implementing and managing overall quality improvement activities in an organization (Usman).

Many researchers have previously researched quality control using the Six Sigma (DMAIC) method in various industries but only a few have researched quality control using the Six Sigma method in the ceramic insulator industry. Previous researchers explained the application of Six Sigma in the water industry (Didiharyono, Marsal \& Bakhtiar, 2018), the application of six sigma in the electronic goods industry, namely the Blue-Ray Disc Player (Dony Arief Widiatmoko), the application of six sigma in the car painting industry (Mohhamed A Rahman, AKM Mohiuddin \& Hanani Abdullah, 2015), the application of six sigma in the construction industry (Molly Thomas \& I.Porcia, 2017).

This study will analyze any failures in the production section of pin post ceramic insulators, as well as find the main causes of the failure of the product and provide suggestions for its repair. This research is also to determine the value of SQL (Sigma Quality Level) in the production section of pin post ceramic insulators.

\section{LITERATURE REVIEW}

A. Control

Control is an activity carried out to monitor activities and ensure that the actual performance carried out is as planned (Vincent Gasperz, 2005).

\section{B. Quality}

Quality is a philosophy that involves all elements of activities carried out by all people in the company that are continuous to achieve a degree of quality and achieve consumer expectations (Achmad.H.S, 2003). 
Defect is a condition in which a product is declared to have failed or does not meet the requirements set by the company or customer (Burhan, 2015).

\section{Six Sigma-Introduction and overview}

At the end of 1970, Dr. Mikel Harry, a senior engineer at Motorola's Government Electronics Group, started an experiment to solve the problem using statistical analysis. Using Motorola's GEG is starting to show dramatic improvements: products are designed and produced faster at less cost. He then wrote this method in a paper entitled "The Strategic Vision for Accelerating Six Sigma Within Motorola", Dr. Mike Harry was then assisted by Richard Schroeder, a former Motorola executive, to develop a datadriven change management concept. The result of this collaboration is a simple quality measurement tool, which later became a philosophy of business progress, known as Six Sigma.

Six sigma is a management tool used to replace Total Quality Management (TQM) which is very focused on quality control by exploring the company's overall production system (Achmad Sutawijaya \& Lenny Nawangsari, 2019). The six sigma method has been widely applied in order to improve performance, such as the manufacturing industry (Linderman, et al., 2003), health and safety (Rimantho \& Cahyadi, 2016; Sanjit, et al., 2011), environmental management systems (Calia, et al., 2009).

\section{RESEARCH METHODOLOGY}

The research methodology used in this research is a case study research with the aim of describing the application of Six Sigma to the ceramic manufacturing industry. Case study-based research engages facilitators to study and work with case study companies.

This study uses primary data and secondary data. Primary data is data that is directly obtained and collected in the research area, such as: the condition of the materials used, work instructions and data of employees who work in the production department. Meanwhile, secondary data is data obtained from indirect sources that have been previously prepared and used for the research process, such as process flow data and employee competency matrices.

Data collection techniques using interviews, observation (direct observation) and documentation. The samples in this study were all internal reports on the production section of pin post ceramic insulators. In analyzing the data using the help of the Minitab 18 application and the Six Sigma calculator.

\section{Define Phase}

\section{RESEARCH RESULTS}

This phase defines the project by identifying critical customer needs and linking them to business needs.

a. Process Flow

A process flow diagram is a diagram showing the general flow of plant processes and equipment. Figure 1 shows a flow diagram of the pin post ceramic insulator production process.

b. SIPOC Diagram

The SIPOC (Supplier, Input, Process, Output and Customer) diagram is a tool for identifying the flow of raw materials, machinery, production processes, finished product output until the receipt of goods by the customer. Figure 2 shows a SIPOC diagram for a pin post insulator section firing.

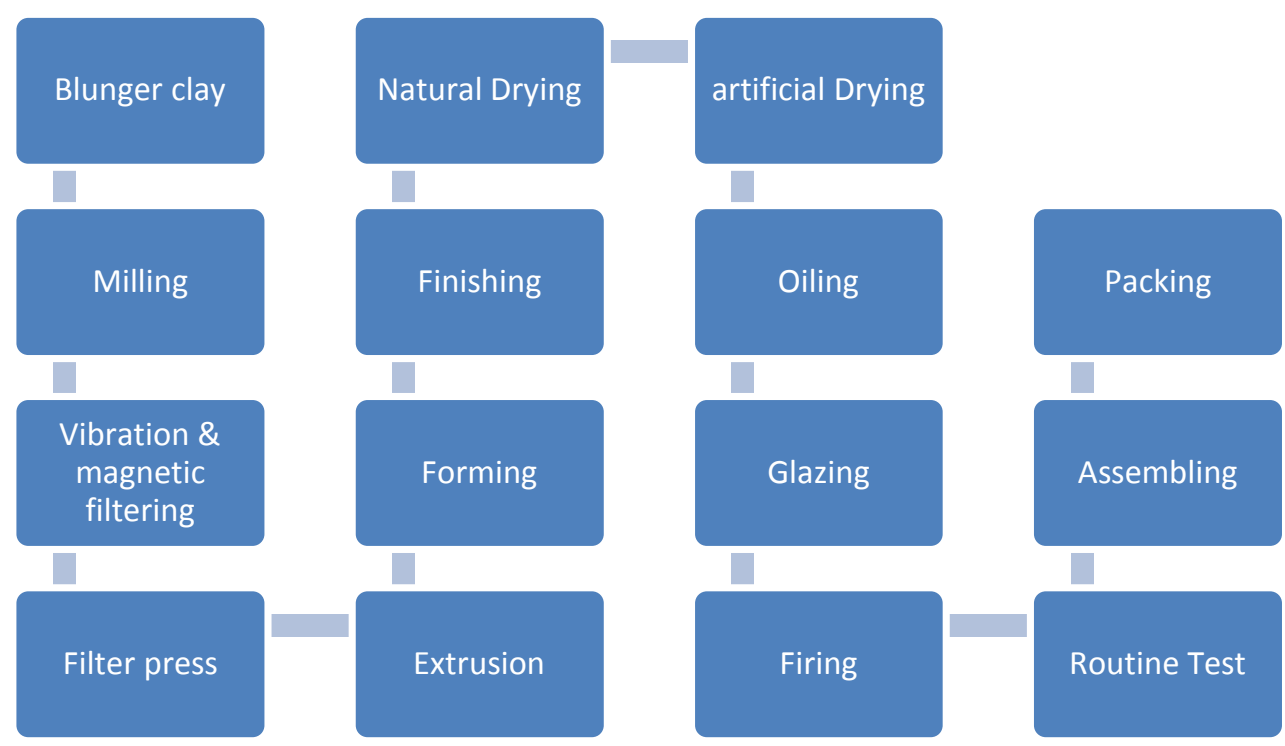

Fig 1: Process Flow of Making Ceramic Pin Post Insulators 
In the Critical To Quality (CTQ) production process, namely the requirements / judgments from QC to achieve customer satisfaction so that there are no complaints from the previous process. Table 1 shows the Critical to Quality (CTQ) production of ceramic post pin insulators in part and Table 2 and Figure 3 show the definition of the type of product defect.

d. Identification of Problems

At this stage the researchers collected data and identified problems that occurred in the quality of the pin post product. Table 3 shows the data for April 2020, there were products that failed in pin post production in finishing section by $10.12 \%$ and the target company value for rejuvenation level. Thus it is necessary to control the quality of production so that production defects can be reduced and product quality is maintained.
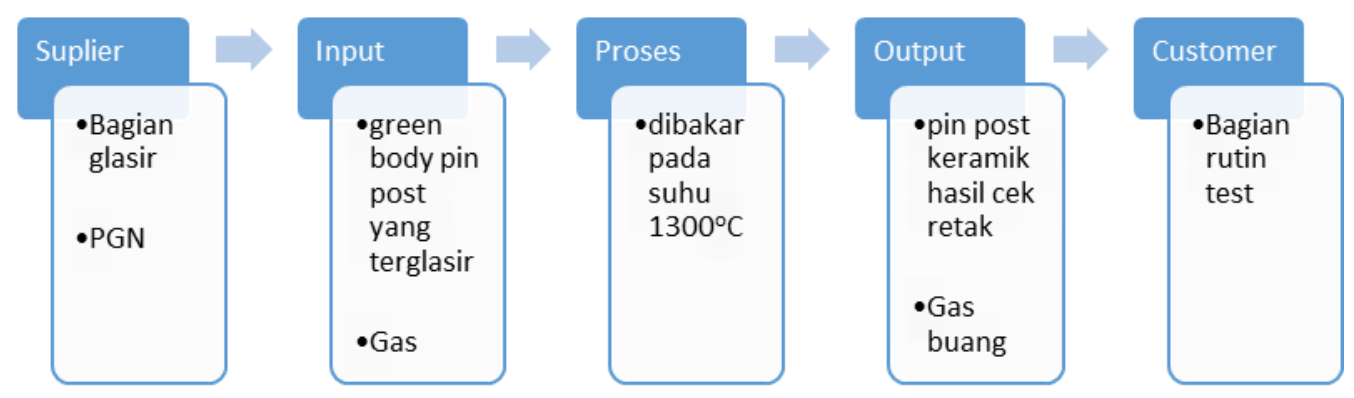

Fig 2 : SIPOC diagram produces Pin Post ceramic insulator

Table 1: CTQ section

\begin{tabular}{|l|l|l|}
\hline Firing Section & \\
\hline Quality characteristics & Performance Requirement & Type of defect \\
\hline Compatibility of visual & Nothing cracked & RA \\
conditions & & RL1 \\
& & RL2 \\
& & RD1 \\
& & RD2 \\
& & RBR \\
& & RDR \\
& & RRT \\
& & RK \\
& & TB \\
& & PB \\
\cline { 3 - 4 } & LM \\
& Brown color and glaze defects & RRA \\
& according to standard & \\
\hline & provisions. & \\
\hline
\end{tabular}


Table 2 : Defect Definition Table

\begin{tabular}{|c|c|c|c|}
\hline No & Code & Name Reject & Definition \\
\hline 1 & Form & $\begin{array}{l}\text { Reject form } \\
\text { forming }\end{array}$ & $\begin{array}{l}\text { The flak from forming because the shape does } \\
\text { not match the image on the leg (tilted leg / dent) }\end{array}$ \\
\hline 2 & Slip & Slip & $\begin{array}{l}\text { When it is formed by the finishing machine, the } \\
\text { finishing knife stops halfway when it forms. }\end{array}$ \\
\hline 3 & RA & Cracked Head & $\begin{array}{l}\text { Cracks at the edge of the upper leaf for the } \\
\text { marking part of the pin post }\end{array}$ \\
\hline 4 & RBR & $\begin{array}{l}\text { Cracked Lip } \\
\text { Skirt }\end{array}$ & $\begin{array}{l}\text { The crack in the middle arch in the skirt from the } \\
\text { pin post }\end{array}$ \\
\hline 5 & RRT & $\begin{array}{l}\text { Crack Middle } \\
\text { Skirt }\end{array}$ & The crack in the center of the radius in the skirt. \\
\hline 6 & RRA & $\begin{array}{l}\text { Top Radius } \\
\text { Crack }\end{array}$ & $\begin{array}{l}\text { The crack in the first neck from the top of the } \\
\text { pin post }\end{array}$ \\
\hline 7 & RK & Cracked Legs & Crack the base of the leg of the pin post \\
\hline 8 & KTR & Dirt & $\begin{array}{l}\text { Dirt sticking to the pin post surface but the dirt } \\
\text { comes from the burning kiln. }\end{array}$ \\
\hline 9 & RD1 & 1st Leaf Crack & That is, the cracked edge of the first leaf \\
\hline 10 & RD2 & 2nd Leaf Crack & Namely the crack at the edge of the second leaf \\
\hline 11 & RL1 & 1st Neck Crack & $\begin{array}{l}\text { The crack in the first neck from the top of the } \\
\text { pin post }\end{array}$ \\
\hline 12 & RL2 & $\begin{array}{l}\text { 2nd Neck } \\
\text { Crack }\end{array}$ & $\begin{array}{l}\text { The crack in the second neck from the top of the } \\
\text { pin post }\end{array}$ \\
\hline 13 & PB & Broken Body & $\begin{array}{l}\text { That is, the pin post is split in two, between the } \\
\text { leg and the body or between the first neck and } \\
\text { the second neck with the feet }\end{array}$ \\
\hline 14 & RDR & Crack In Skirt & $\begin{array}{l}\text { Cracks in the radius in the skirt, into the body } \\
\text { (sideways and not in the middle of the radius) }\end{array}$ \\
\hline 15 & LM & Laminate & $\begin{array}{l}\text { Cracks in the body of the pin post. The fractions } \\
\text { looked twisted }\end{array}$ \\
\hline 16 & SOMPEL & Sompel & $\begin{array}{l}\text { That is a small fraction in a certain part of the pin } \\
\text { post }\end{array}$ \\
\hline 17 & PUNTIRAN & Twist & $\begin{array}{l}\text { The twisted fracture of the leg due to the forming } \\
\text { / pugmill }\end{array}$ \\
\hline 18 & TB & Paste Material & $\begin{array}{l}\text { The remaining material that sticks during the } \\
\text { forming process (usually attached to the inside } \\
\text { of the pin post skirt) }\end{array}$ \\
\hline 19 & PK & Broken leg & $\begin{array}{l}\text { The pinpost leg was broken with the body and } \\
\text { skirt }\end{array}$ \\
\hline 20 & PL1 & $\begin{array}{l}\text { 1st neck } \\
\text { fracture }\end{array}$ & $\begin{array}{l}\text { Fracture of the first neck from above the pin } \\
\text { post as a result of mechanical stress }\end{array}$ \\
\hline 21 & PL2 & $\begin{array}{l}\text { 2nd neck } \\
\text { fracture }\end{array}$ & $\begin{array}{l}\text { Fracture in the second neck from the top of the } \\
\text { pin post as a result of mechanical stress }\end{array}$ \\
\hline \multirow[t]{9}{*}{22} & \multirow[t]{9}{*}{ C.GLZ } & & $\begin{array}{l}\text { Spot without glaze or insert small objects on the } \\
\text { glaze layer and small holes. Where the provision } \\
\text { is that the total glaze defect area in each insulator } \\
\text { unit must not exceed: } \\
\qquad 100 x \frac{D X F}{2000}\end{array}$ \\
\hline & & & And every single glaze defect must not exceed: \\
\hline & & & $50 x \frac{D X F}{20000}$ \\
\hline & & & $\mathrm{D}=$ largest diameter of the insulator \\
\hline & & & $\mathrm{F}=$ The creepage distance of the insulator \\
\hline & & & $\begin{array}{l}\text { So for pin posts, the total glaze defects must not } \\
\text { exceed: }\end{array}$ \\
\hline & & & $100 \times 170 \times 534 / 2000=4539 \mathrm{~mm} 2$ \\
\hline & & & And every single glaze defect must not exceed: \\
\hline & & & $50 \times 170 \times 534 / 20000=226,95 \mathrm{~mm} 2$. \\
\hline
\end{tabular}




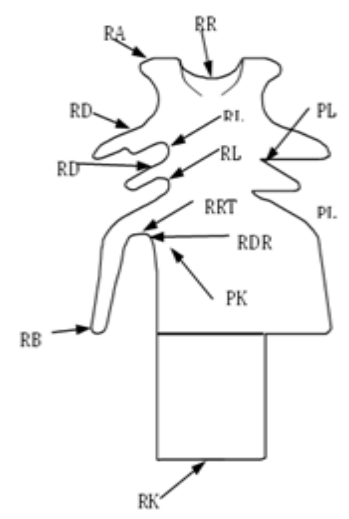

Fig 3 : Types of Pin Post defects

Table 3 : Production data of pin post insulators in April 2020 and company defect target.

\begin{tabular}{|l|c|c|c|c|}
\hline \multirow{2}{*}{ Bagian Proses } & \multicolumn{3}{|c|}{ April 2020 } & \\
\cline { 2 - 4 } & Total produksi & Rijek & \% Rijek & Target Rijek \\
\hline Finishing & 20.750 & 232 & 1,12 & $0,40 \%$ \\
\hline Natural Drying & 21.556 & 532 & 2,47 & $0,50 \%$ \\
\hline Oiling & 21.013 & 1.767 & 8,41 & $3,50 \%$ \\
\hline Firing & 19.152 & 0 & 0,00 & $2,50 \%$ \\
\hline Rutin Test & 15.830 & 147 & 0,93 & $0,80 \%$ \\
\hline
\end{tabular}

\section{e. $\quad$ Project Chapter}

In making a project chapter, the most important thing is to make a goal statement. The objective statement must be specific and measurable, because it becomes the basis for improvement efforts (Desai et al., 2014). Then the goal statement is seen in table 4.

\section{Measure Phase}

The measure phase consists of finding and executing the data that has been collected to establish the basics of improvement and measuring the CTQ as the target process and calculating the sigma level value.

\section{a. Production Control Chart}

To create a control chart and binomial capabilities of each production section, researchers used the help of the Minitab 18 application. Figure 4: shows the control chart and capabilities in the finishing, natural drying, oiling, combustion and routine test sections.

Table 4 : Project Chapter

\begin{tabular}{|c|c|}
\hline \multicolumn{2}{|c|}{ PROJECT CHAPTER } \\
\hline BUSINESS CASE & OPPORTUNITY STATEMENT \\
\hline $\begin{array}{l}\text { Production rejects in April } 2020 \text { in several parts } \\
\text { of the production did not reach the target set by } \\
\text { the company, in section: }\end{array}$ & $\begin{array}{l}\text { The production reject in April } 2020 \text { in several } \\
\text { parts of the production did not reach the target } \\
\text { set by the company, as a result, production in } \\
\text { April lost as much as: }\end{array}$ \\
\hline $\begin{array}{l}\text { - Finishing section reject is } 1.18 \% \text { while the } \\
\text { target is } 0.4 \%\end{array}$ & $\begin{array}{l}\text { - finishing section: } 149 \mathrm{pcs}(0.78 \% \text { of April } 20 \\
\text { production) }\end{array}$ \\
\hline $\begin{array}{l}\text { - Natural drying section reject is } 2.46 \% \text { while the } \\
\text { target is } 0.5 \%\end{array}$ & $\begin{array}{l}\text { - natural drying section: } 424 \mathrm{pcs} \text { (1.96\% of } \\
\text { April } 20 \text { production) }\end{array}$ \\
\hline $\begin{array}{l}\text { - Oiling section reject is } 8.4 \% \text { while the target is } \\
3.5 \%\end{array}$ & $\begin{array}{l}\text { - oiling section: } 1,029 \mathrm{pcs} \text { ( } 4.9 \% \text { of April } 20 \\
\text { production) }\end{array}$ \\
\hline $\begin{array}{l}\text { - Firing section reject is } 10.1 \% \text { while the target is } \\
2.5 \%\end{array}$ & $\begin{array}{l}\text { - firing section: } 1,130 \mathrm{pcs} \text { ( } 7.6 \% \text { of April } 20 \\
\text { production) }\end{array}$ \\
\hline $\begin{array}{l}\text { - Routine Test reject is } 0.92 \text { while the target is } \\
0.8 \% \text {. }\end{array}$ & $\begin{array}{l}\text { - routine test section: } 19 \mathrm{pcs}(0.12 \% \text { of } \\
\text { production April 20). }\end{array}$ \\
\hline GOAL STATEMENT & PROJECT SCOPE \\
\hline $\begin{array}{l}\text { "Reducing the pin post production flux in the } \\
\text { finishing section from } 1.12 \% \text { to } 0.4 \% \text {, the natural } \\
\text { drying portion from } 2.49 \% \text { to } 0.5 \% \text {, the oiling } \\
\text { portion from } 8.41 \% \text { to } 3.5 \% \text {, the combustion } \\
\text { portion of } 10.21 \% \text { to } 2.5 \% \text { and the routine test } \\
\text { portion from } 0.93 \% \text { to } 0.8 \% \text {, at the end of } \\
\text { semester } 1 \% \text {. }\end{array}$ & $\begin{array}{l}\text { Scope : } \\
\text { Production in the finishing section, natural } \\
\text { drying, oiling, firing and routine tests }\end{array}$ \\
\hline
\end{tabular}




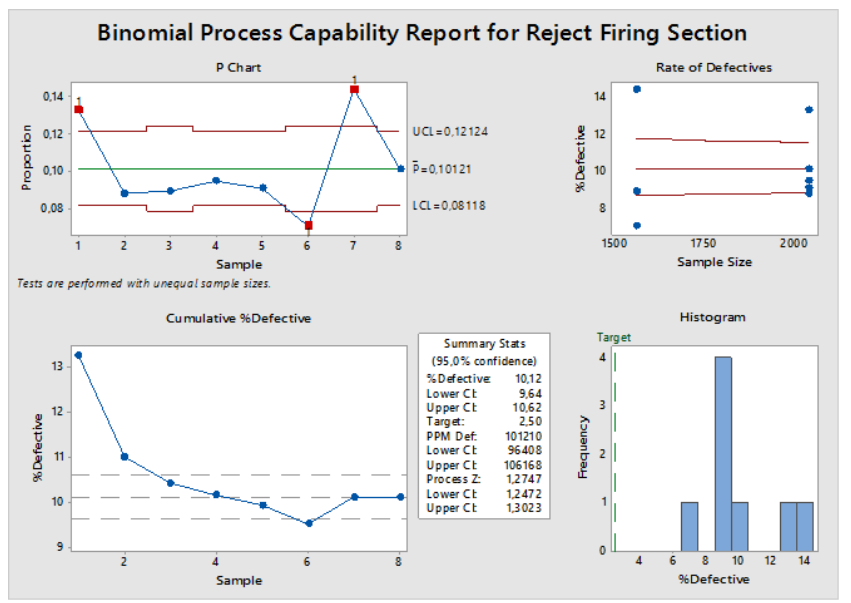

Fig 4 : control chart and capabilities in the finishing, natural drying, oiling, combustion and routine test sections.

\section{b. Calculating the Sigma Leve}

In calculating the value of DPO and DPMO using historical data for April 2020, which shows the capability of the process before repair. Measurement of the six sigma level with the help of the six sigma calculator application. Table 5. shows the results of the calculation of DPO, DPMO and six sigma level.

Table 5 : The six sigma calculation results table

\begin{tabular}{|l|c|c|c|}
\hline Proses & DPO & DPMO & Level Sigma \\
\hline Finishing & 0,011180723 & 11180,723 & 3,78 \\
\hline Natural Drying & 0,024679904 & 24679,904 & 3,47 \\
\hline Oiling & 0,084090801 & 84090,801 & 2,88 \\
\hline Firing & 0,101209677 & 101209,677 & 2,77 \\
\hline Rutin test & 0,009286166 & 9286,166 & 3,85 \\
\hline
\end{tabular}

\section{Analyze Phase}

In the Analyze Phase, the root cause of the problem is determined using the Pareto diagram from the QC data and fishbone diagrams.

\section{a. Pareto Diagram}

The Pareto chart is a tool that can determine which improvements need priority.

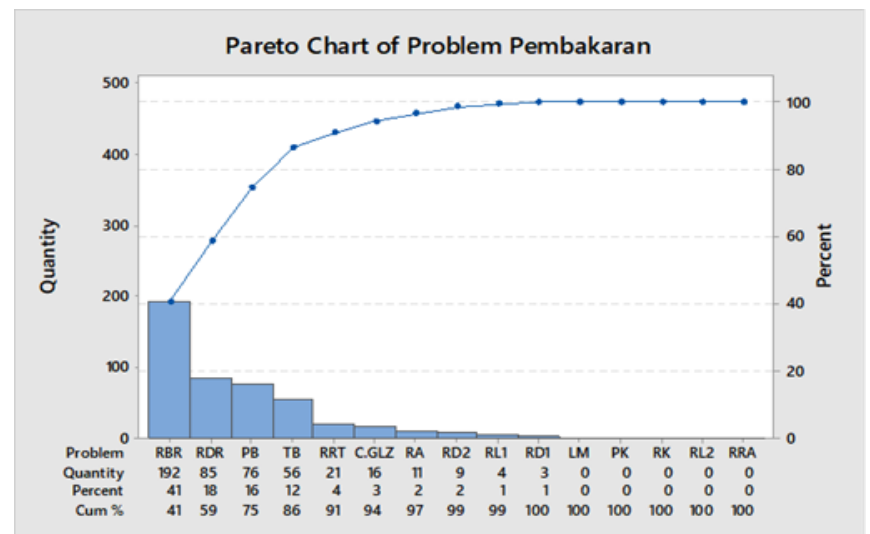

Fig 4 : Pareto diagram parts of finishing, natural drying, oiling, burning and routine tests.

\section{b. Fishbone Diagram}

In finding the source of the cause of the defect, this study conducted direct interviews with sources who were considered to be experts to obtain information about the causes of potential defects, then a Fisbone Diagram was made to be able to determine the causes of the defect. After that, from the possible root cause fishbone diagram, discussions and field observations were made to obtain the root cause. The figure in the appendix 1 shows a fishbone diagram by section. 


\section{Improve Phase}

At the Improve phase, an analysis of corrective actions will be carried out to overcome the problem of reducing pin post insulator pressure, then calculating the back using the 5W1H concept (Why, When, Who, Where, What and How). Table 6 shows $5 \mathrm{~W} 1 \mathrm{H}$ to solve the root cause.

\section{Control Phase}

The control phase in the DMAIC approach is about maintaining the changes made in the improve phase. Table 7 is a control to maintain the changes made in the problem improvement phase.

a. Analysis capabilities

Capability analysis is a comparison of process performance after repair with specified requirements and before repair. Appendix 2 shows the analytical capabilities of each section.

b. Calculates the six sigma level

After getting the data from the results of the improve, the DPMO calculation is done again to determine the next performance. Table 8 shows the results of the calculation of the six sigma level after the improve phase.

Tabel 6 : Table 5W1H

\begin{tabular}{|c|c|c|c|c|c|c|c|}
\hline No & Penyebab & Why & What & Where & When & Who & How \\
\hline 1 & $\begin{array}{l}\text { Vaccum in the } \\
\text { finishing part is not } \\
\text { stable (too big or } \\
\text { small) }\end{array}$ & $\begin{array}{l}\text { Because the vaccum } \\
\text { duct is clogged with } \\
\text { residual dirt }\end{array}$ & $\begin{array}{l}\text { Vacuum lines cleared } \\
\text { and operator finishing } \\
\text { at briefings }\end{array}$ & $\begin{array}{l}\text { in the } \\
\text { finishing } \\
\text { section }\end{array}$ & 18-May-20 & Maintenace & $\begin{array}{l}\text { Vaccum finishing line } \\
\text { cleaning and routine } \\
\text { maintenance checks }\end{array}$ \\
\hline 2 & $\begin{array}{l}\text { The auger pugmill or } \\
\text { extruder has wom } \\
\text { more than } 5 \mathrm{~mm}\end{array}$ & $\begin{array}{l}\text { Because } 45,597 \mathrm{~km} \\
\text { have been used, it } \\
\text { needs maintenance }\end{array}$ & $\begin{array}{l}\text { Repair of the auger } \\
\text { and maintenance } \\
\text { standards were } \\
\text { established }\end{array}$ & $\begin{array}{l}\text { in the } \\
\text { extruder }\end{array}$ & 08-Jun-20 & Maintenace & $\begin{array}{l}\text { Repair of the auger by } \\
\text { patching worn augers } \\
\text { and making a pugmill } \\
\text { wear checkset that } \\
\text { converts from pcs to } \\
\text { m for periodic } \\
\text { maintenance }\end{array}$ \\
\hline 3 & $\begin{array}{l}\text { Operators in entering } \\
\text { the feeder into the } \\
\text { mold forming as long } \\
\text { as it is not } \\
\text { perpendicular. }\end{array}$ & $\begin{array}{l}\text { Because the going in } \\
\text { forming is not } \\
\text { perpendicular because } \\
\text { the pugmill operator is } \\
\text { in a hurry to put the } \\
\text { going into the lorry. }\end{array}$ & $\begin{array}{l}\text { Pugmill operators are } \\
\text { trained to put the going } \\
\text { so as not to tilt. }\end{array}$ & $\begin{array}{l}\text { on the } \\
\text { pugmill } \\
\text { section }\end{array}$ & 08-Jun-20 & $\begin{array}{l}\text { Operator } \\
\text { pugmill }\end{array}$ & $\begin{array}{l}\text { Pugmill operator } \\
\text { training for laying } \\
\text { down and consistent } \\
\text { monitoring of work by } \\
\text { the Head of } \\
\text { Formation. }\end{array}$ \\
\hline 4 & $\begin{array}{l}\text { Between the } H G \text { in the } \\
\text { forming section and } \\
\text { the seized part in the } \\
\text { finishing section, the } \\
\text { dimensions don't } \\
\text { match }\end{array}$ & $\begin{array}{l}\text { By checking the results } \\
\text { of the forming form } \\
\text { are placed in seized, } \\
\text { the result is that the lip } \\
\text { of the skirt does not } \\
\text { reach the confiscated } \\
\text { stoper. }\end{array}$ & $\begin{array}{l}\text { Repairs are carried out } \\
\text { for confiscation and } \\
\text { standards are made for } \\
\text { maintenance. }\end{array}$ & $\begin{array}{l}\text { in the } \\
\text { finishing } \\
\text { section }\end{array}$ & 25-Jun-20 & $\begin{array}{l}\text { Finishing } \\
\text { and } \\
\text { maintenanc } \\
\text { e operators }\end{array}$ & $\begin{array}{l}\text { Use the checksheet for } \\
\text { use of } \mathrm{HG} \text { and } \\
\text { confiscated molds and } \\
\text { check the similarity of } \\
\text { dimensions of } \\
\text { confiscated and } \mathrm{HG} \\
\text { after each use of } \\
20,000 \text { pcs for } \\
\text { maintenance }\end{array}$ \\
\hline 5 & $\begin{array}{l}\text { There is no torsional } \\
\text { measurement for } Y G \\
\text { mold results }\end{array}$ & $\begin{array}{l}\text { Because the most } \\
\text { recent measurement is } \\
\text { sufficient as a } \\
\text { reference for checking } \\
\text { the measured } \\
\text { measurements. }\end{array}$ & $\begin{array}{l}\text { Dilakukan pengecekan } \\
\text { untuk puntiran YG dan } \\
\text { operator diberi } \\
\text { training. }\end{array}$ & $\begin{array}{l}\text { in the } \\
\text { forming } \\
\text { section }\end{array}$ & 23-Jun-20 & $\begin{array}{l}\text { Forming } \\
\text { operator, } \\
\text { Head of } \\
\text { forming } \\
\text { and QC }\end{array}$ & $\begin{array}{l}\text { Making a check sheet } \\
\text { for } Y G \text { measurement } \\
\text { and setting the rotation } \\
\text { standard for } Y G \text {, } \\
\text { namely } 90 \text { degrees. }\end{array}$ \\
\hline
\end{tabular}




\begin{tabular}{|c|c|c|c|c|c|}
\hline No & Control & Tool & $\begin{array}{c}\text { How to } \\
\text { often }\end{array}$ & Checking & Who \\
\hline \multirow[t]{2}{*}{1} & V accum & $\begin{array}{l}\text { Maintenance } \\
\text { checklist }\end{array}$ & Monthly & V accum duct & Maintenance \\
\hline & & $\begin{array}{l}\text { Production } \\
\text { checklist }\end{array}$ & Daily & $\begin{array}{l}\text { Work } \\
\text { consistency }\end{array}$ & $\begin{array}{l}\text { Head of } \\
\text { F orming } \\
\text { Section }\end{array}$ \\
\hline 2 & Auger & $\begin{array}{l}\text { Extruder usage } \\
\text { checksheet }\end{array}$ & Monthly & $\begin{array}{l}\text { L ength } x \\
\text { production } \\
\text { pcs }\end{array}$ & Maintenance \\
\hline 3 & \begin{tabular}{|l|} 
Consistent \\
insertion of \\
going into \\
mold forming
\end{tabular} & $\begin{array}{l}\text { Production } \\
\text { checklist }\end{array}$ & Daily & $\begin{array}{l}\text { Work } \\
\text { consistency }\end{array}$ & \begin{tabular}{|l} 
Head of \\
Forming \\
Section
\end{tabular} \\
\hline 4 & $\begin{array}{l}\text { HG } \\
\text { compatibility } \\
\text { with sita }\end{array}$ & $\begin{array}{l}\text { Production } \\
\text { checklist }\end{array}$ & Weekly & $\begin{array}{l}\text { Number of } \\
\text { production }\end{array}$ & $\begin{array}{l}\text { Forming } \\
\text { operators, } \\
\text { finishing and } \\
\text { forming } \\
\text { techricians. }\end{array}$ \\
\hline 5 & YG twist & $\begin{array}{l}\text { Y G checking } \\
\text { checksheet }\end{array}$ & Daily & $\begin{array}{l}\text { Degree of } \\
\text { twisting }\end{array}$ & $\begin{array}{l}\text { Forming } \\
\text { operator, Head } \\
\text { of forming and } \\
\text { QC }\end{array}$ \\
\hline
\end{tabular}

Table 7 : Table control after improvement

Table 8 : The table is the calculation result of DPO, DPMO and six sigma level after the upgrade stage.

\begin{tabular}{|l|c|c|c|}
\hline Proses & DPO & DPMO & Level Sigma \\
\hline Finishing & 0,002962963 & 2962,963 & 4,25 \\
\hline Natural Drying & 0,003800601 & 3800,601 & 4,17 \\
\hline Oiling & 0,031134374 & 31134,374 & 3,93 \\
\hline Firing & 0,018872549 & 18872,549 & 3,58 \\
\hline Rutin test & 0,002576828 & 2576,828 & 4,3 \\
\hline
\end{tabular}

From the table, it is found that the results of the improvements that have been made can reduce the DPMO value, in the firing section from 101209.67 to 18872.54. Meanwhile, there was an increase in the sigma value, in the firing section from 2.77 to 3.58.

\section{CONCLUSIONS}

Based on the results of the research that has been done, it can be concluded that:

In the firing section, rijek occurs: RDR (inner skirt crack), RBR (skirt lip crack) and PB (broken body). With the main causes, namely: the pugmill machine is worn out, the dimensions of the Honggote (HG) shape in the forming and seizure sections are not matching, vaccum finishing is not stable, and there is no measurement of the twist of the Yobigote (YG) twist. The reasons for this were repaired as follows: cleaning the vaccum ducts in the finishing section are kept clean from material impurities, auger repairs by patching worn augers and periodic maintenance, repair of Sita and HG to match the radius and periodic maintenance and routine checking twist of YG and making new SOPs.

Using the Six Sigma method has a positive effect on the quality of the products produced. This is shown by increasing the six sigma level.

\section{REFFERENCES}

Arini T. Soemohadiwidjojo 2017, Six Sigma Metode Pengukuran Kinerja Perusahaan Berbasis Statistik. Jakarta : Raih Asa Sukses.

Vicent Gaspersz 2008, The Executive Guide To Implementing Lean Six Sigma. Jakarta : PT Gramedia Pustaka Utama.

Murdifin Haming \& Mahfud Nurnajjamuddin 2007, Manajemen Produksi Modern Operasi Manufaktur dan Jasa, Jakarta : PT. Bumi Aksara.

Achmad H Sutawidjaya \& Lenny C Nawangsari 2019, Strategi Operasi \& Proses Manajemen, Jakarta : Lembaga Pengkajian Dan Pengembangan Sumber Daya, Bengkulu.

Humiras Hardi Purba, S.T., M.T. \& Siti Aisyah, S.T., M.T 2017, Quality Improvement and Lean Six Sigma. Yogyakarta : Expert.

Michael L. George, David Rowlands, Mark Piece, John Maxey 2005, Lean Six Sigma Pocket Toolbook. Unites states : McGrawHill.

C. Tri Hendradi, Statistik Six Sigma dengan minitab panduan cerdas insiatif kualitas. Yogyakarta : CV. ANDI 
Yanto, Statistikinferensi untuk penelitian dengan minitab. Yogyakarta : CV. ANDI

Erdi Hermawan (2018). Analisis Pengendalian Kualitas Dengan Pendekatan Metode Six Sigma (studi kasus di PT XYZ).

Fidin Saptaaji (2018). Analisa Penurunan Tingkat Reject Claim Plate Bengkok.

Sulkhan (2018). Rekayasa Perbaikan Kualitas Proses Plating Melalui Implementasi Metode Six Sigma.

Hani Sirine, Elisabeth Penti Kurniawati 2017, 'Pengendalian Kualitas Menggunakan Metode Six Sigma (Studi Kasus pada PT. Diras Concept Sukoharjo)', AJIE - Asian Journal of Innovation and Entrepreneurship Vol. 02, No. 03.

Didiharyono, Marsal, Bakhtiar 2018, 'Analisa Pengendalian Kualitas Produksi Dengan Metode Six Sigma Pada Industri Air Minum PT Asera Tirta Posidonia, Kota Palopo’, Jurnal Sainsmat, Halaman 163-176 Vol. VII, No.2

Dino Rimantho, Desak Made Mariani 2017, 'Penerapan Metode Six Sigma Pada Pengendalian Kualitas Air Baku Pada Produksi Makanan', Jurnal ilmiah Teknis Industri, ISSN: 1412-6869 e-ISSN: 2480-4038.

Ismi Wulandari, Merita Bernik 2016, 'Penerapan Metode Pengendalian Kualitas Six Sigma Pada Heyjacker Company', EkBis: Jurnal Ekonomi dan Bisnis, Vol. 1, No. 2. Halaman 222 - 241.

Endi Haryanto dan Bonivasius Prasetya Ichtiarto 2019, 'Analisa Punurunan Cacat (Defect) Cat Bintik Debu Dengan Metodologi Six Sigma Pada Proses Painting Produk Fuel Tank Di PT. SSO Tanggerang', Jurnal Penelitian dan Aplikasi Sistem \& Teknik Industri (PASTI) Vol. XIII, No. 3.

Dony Arief Widiatmoko dan Waseso Segoro 2015, 'Aplikasi 6 Sigma Dalam Menurunkan Malfunction Defect Di Pengetesan Elektrikal (AC Transient Test) Pada Tahapan Pengembangan Produk Blu-Ray Disc Player (Studi Kasus Di Perusahaan Manufaktur Elektronik), Jurnal MIX, Volume V, No. 3

Benny Ferdyan 2015, 'Analisis Peningkatan Kualitas Manufacture Switchgear SM6 Dengan Metode DMAIC untuk mengurangi Tingkat Manufacture Defect Rate (MDR) Di PT. Schneider Electric Indonesia Cikarang Plant', Jurnal OE, Volume VII, No. 2.

A.Kumaravadivel, U.Natarajan 2011, 'Empirical study on employee job satisfaction upon implementing six sigma DMAIC methodology in Indian foundry- A case study', International Journal of Engineering, Science and Technology, Vol. 3, No. 4, 2011, pp. 164-184.

Mohamed A Rahman, A.K.M. Mohiuddin, and Hanani Abdullah 2015, Painting Process Improvement Through Six Sigma Approach In A Malaysian Vechile Assembly Company’, Advanced Materials Research Vol. 1115 (2015) pp 596-600.

K.Srinivasan, S. Muthu, N.K.Prasad, G.Satheesh 2014, 'Reduction of paint line defects in shock absorber through Six Sigma DMAIC phases', 12th GLOBAL CONGRESS ON MANUFACTURING AND MANAGEMENT, Procedia Engineering 97 ( 2014 ) $1755-1764$.

Javedhusen Malek, Darshak Desai 2015, 'Reducing Rejection/Rework In Pressure Die Casting Process By Application Of DMAIC Methodology Of Six Sigma', International Journal for Quality Research 9(4) 577-604

Darshak A.Desai and Aurangzeb Javed Ahmed Shaikh, 2018, 'Reducing failure rate at high voltage (HV) testing of insulator using Six Sigma methodology', International Journal of Productivity and Performance Management, Volume 67 Issue 5, 31 May 2018.

Sachin S, Dileeplal J 2017, Six Sigma Methodology for Improving Manufacturing Process in Faoundry Industry, International Journal of Advanced Engineering Research and Science (IJAERS), Vol-4, Issue-5

M.Shanmugaraja and M. Nataraj, N. Gunasekaran 2011, Quality and productivity improvement using six sigma and Taguchi methods, Int. J. Business Excellence, Vol. 4, No. 5.

Jirasukprasert, P. , Garza-Reyes, J. A. , Kumar, V. and Lim, M. K. (2014), 'A Six Sigma and DMAIC application for the reduction of defects in a rubber gloves manufacturing process', International Journal of Lean Six Sigma, volume 5 (1): 2-21. 
Sharma, G. V. S. S.; Rao, P. Srinivasa; Babu, B. Surendra 2018, 'Process capability improvement through DMAIC for aluminum alloy wheel machining', Journal of Industrial Engineering International, ISSN 2251-712X, Springer, Heidelberg, Vol. 14, Iss. 2, pp. 213-226.

Ankit Dubey, Sonam Yadav 2016, 'Implementation of six sigma DMAIC methodology in precast industry for quality improvement', International Research Journal of Engineering and Technology (IRJET), Volume: 03 Issue: 11.

S. Sriram, A. Revathi 2016, 'Implementation of Six Sigma Concepts in Construction Project for Ensuring Quality Improvements', International Journal of Innovative Research in Science, Engineering and Technology, Vol. 5, Issue 4.

Suraj Dhondiram Patil, M M Ganganallimath, Roopa B Math, Yamanappa Karigar 2015, 'Application of Six Sigma Method to Reduce Defects in Green Sand Casting Process: A Case Study', International Journal on Recent Technologies in Mechanical and Electrical Engineering (IJRMEE), Volume: 2 Issue: 6.

Molly Thomas, L. Porcia 2017, 'Effectiveness of Implementation of Lean Six Sigma Techniques in Contruction', International Journal of Advances in Science Engineering and Technology, Volume-5, Issue-3, Jul.-2017.

K. Srinivasan, S. Muthu, S. R. Devadasan \& C. Sugumaran 2016, 'Enhancement of sigma level in the manufacturing of furnace nozzle through DMAIC approach of Six Sigma: a case study', Production Planning \& Control The Management of Operations, http://dx.doi.org/10.1080/09537287.2016.1143130.

YA Rochman and A Agustin 2017, 'Minimization of Defective Products in The Department of Press Bridge \& Rib Through Six Sigma DMAIC Phases’, IOP Conf. Series: Materials Science and Engineering 215 (2017) 012035.

Safrizal, Muhajir 2016, 'Pengendalian Kualitas dengan Metode Six Sigma', Jurnal Mamanjemen Dan Keuangan, VOL.5, NO.2.

Nur Ainah 2015, 'Definisi Pengendalian, Fungsi dan Tujuan Pengendalian', diakses pada 21 April 2020 , http://nurarinahidayah.blogspot.com/2015/03/definisi-pengendalian-fungsi-dan-tujuan.htm.

Budi Kho 2019, 'Ilmu Manajemen Industri Pengertian Six Sigma dan Tahapan DMAIC', diakses pada 21 April 2020 , https://ilmumanajemenindustri.com/pengertian-six-sigma-5-tahapan-six-sigma-dmaic/.

Margie Subahagia Ningsih, Esmi Mada 2018, Metode Six Sigma untuk Mengendalikan Kualitas Produk Surat Kabar di PT X, JURITI PRIMA (Jurnal Ilmiah Teknik Industri Prima), Vol.2; No.1. 
APPENDIX 1

Diagran Fishbone Bagian Pembakaran Rijek RDR

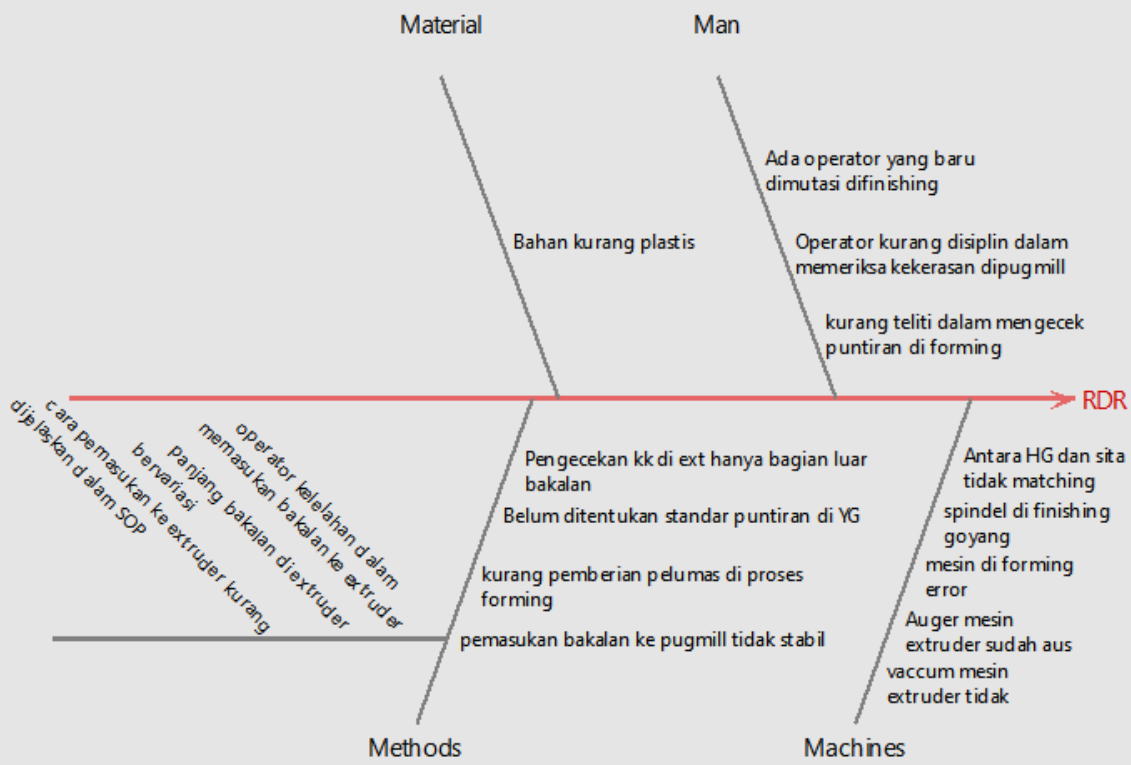

\section{Diagran Fishbone Bagian Pembakaran Rijek RBR}

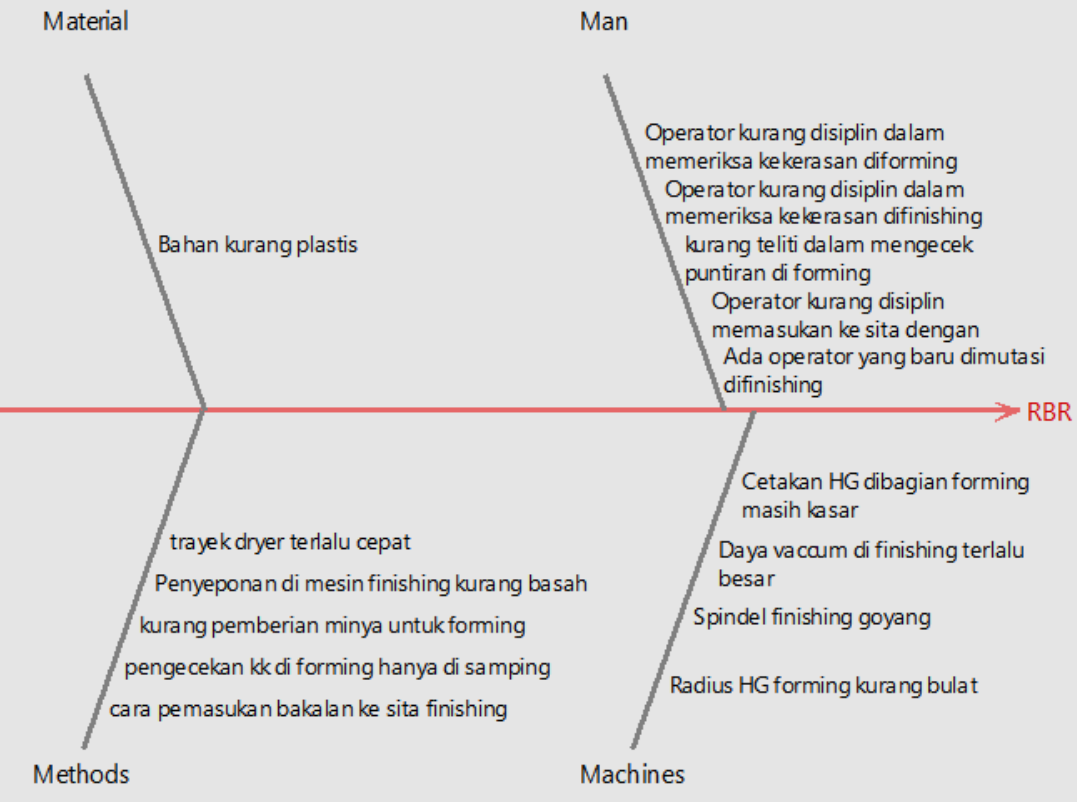




\section{Diagran Fishbone Bagian Pembakaran Rijek PB}

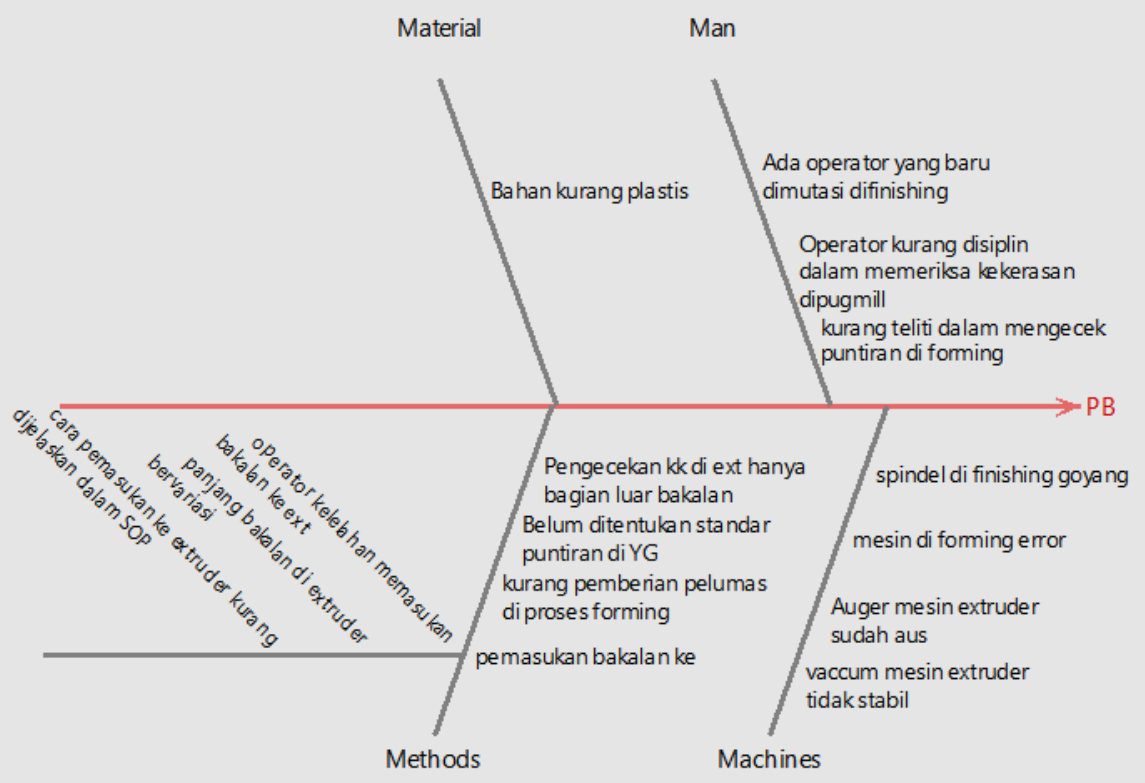


APPENDIX 2
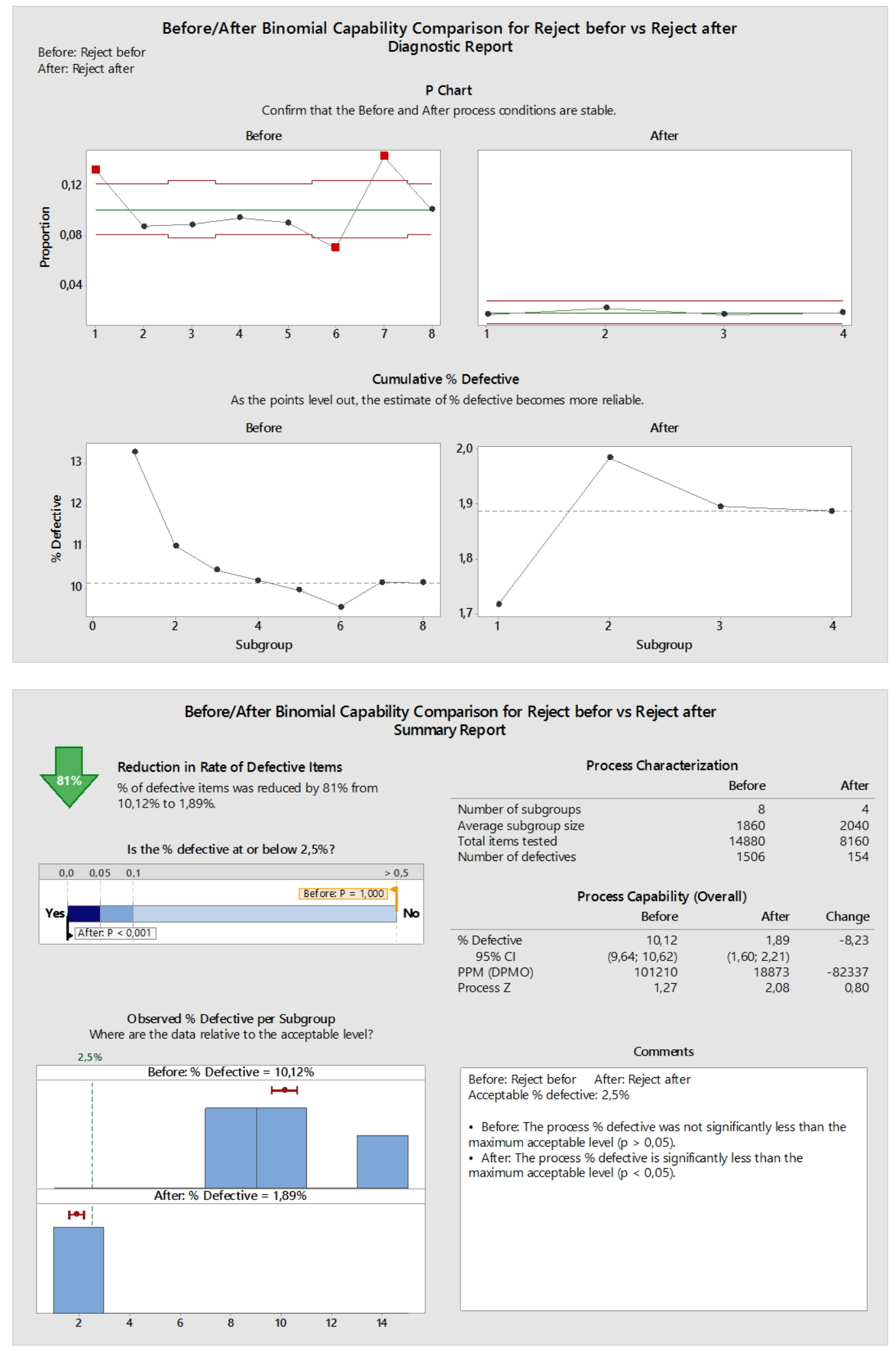